\title{
Znaczenie przetrwałego otworu owalnego u pacjenta kwalifikowanego do zabiegu ortotopowego przeszczepienia wątroby
}

\section{Significance of the patent foramen ovale for the candidate to the orthotopic liver transplantation}

\author{
Katarzyna Żukowska ${ }^{1}$, Piotr Kędzierski ${ }^{1}$, Michalina Galas ${ }^{1}$, Arkadiusz Pietrasik ${ }^{1}$, Piotr Scisło ${ }^{1}$, \\ Joanna Raszeja-Wyszomirska², Renata Główczyńska ${ }^{1}$ \\ ${ }^{1}$ I Katedra i Klinika Kardiologii Warszawskiego Uniwersytetu Medycznego \\ ${ }^{2}$ Klinika Hepatologii i Chorób Wewnętrznych Katedry Chirurgii Ogólnej, Transplantacyjnej i Wątroby \\ Warszawskiego Uniwersytetu Medycznego
}

\section{Streszczenie}

Przetrwały otwór owalny (PFO) to wrodzona wada przegrody międzyprzedsionkowej, która w większości przypadków nie ujawnia się klinicznie. Jednak w warunkach doprowadzających do przewyższenia wartości ciśnienia w prawym przedsionku nad lewym przedsionkiem może stanowić przyczynę przecieku prawo-lewego. W artykule przedstawiono przypadek 63-letniego mężczyzny ze schyłkową niewydolnością wątroby marskiej, kwalifikowanego do zabiegu ortotopowego przeszczepienia wątroby. U pacjenta podczas przezprzełykowego badania echokardiograficznego z użyciem kontrastu stwierdzono PFO. W literaturze istnieją opisy przypadków sugerujące podwyższone ryzyko okołooperacyjne w grupie pacjentów z PFO, które ma wynikać z ryzyka powstawania zatorów powietrznych podczas transplantacji wątroby, jak i, dodatkowo, z możliwości powstania zatorów skrzyżowanych przez PFO. Z tego powodu podjęto decyzję o przezskórnym zamknięciu PFO przed planowanym przeszczepieniem. Po wykonanym zabiegu pacjenta zakwalifikowano do operacji transplantacji wątroby, która odbyła bez powikłań, miesiąc po zamknięciu ubytku.

Słowa kluczowe: zaawansowana niewydolność wątroby, ortotopowe przeszczepienie wątroby, przetrwały otwór owalny, zator paradoksalny, zator powietrzny

Folia Cardiologica 2017; 12, 5: 493-496

\section{Wstęp}

Ortotopowe przeszczepienie wątroby (OLTx, orthotopic liver transplantation) jest uznaną metodą leczenia chorych z zaawansowaną niewydolnością wątroby (ESLD, end-stage liver disease). Według wytycznych Europejskiego Towarzystwa Kardiologicznego (ESC, European Society of Cardiology) dotyczących operacji niekardiochirurgicznych, zabieg obarczony jest dużym (> 5\%) ryzykiem powikłań sercowo-naczyniowych [1]. Kwalifikacja kardiologiczna do zabiegu OLTx obejmuje między innymi przezklatkowe badanie echokardiograficzne.

Przetrwały otwór owalny (PFO, patent foramen ovale), obecny u około $25 \%$ populacji dorosłych, zazwyczaj jest wadą bezobjawową [2]. Jednak wzrost i przewaga ciśnienia w prawym przedsionku nad ciśnieniem w lewym przedsion- 


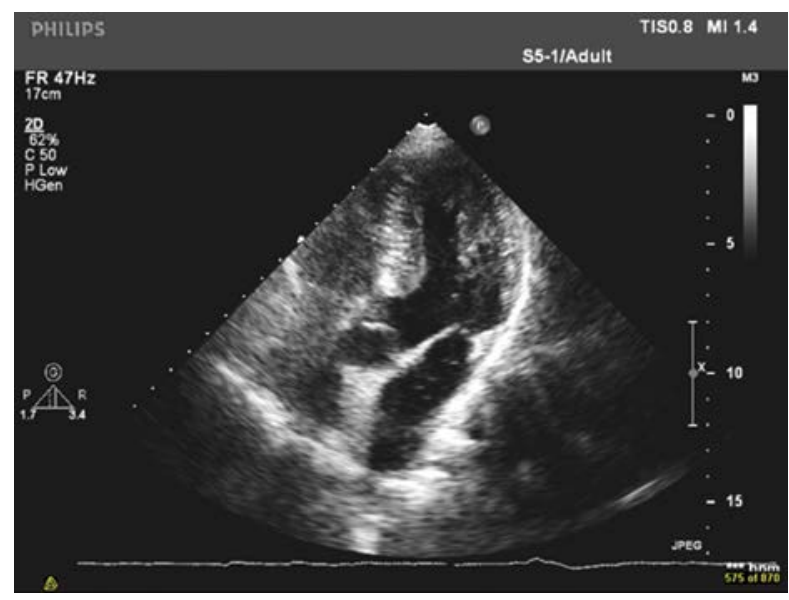

Rycina 1. Badanie echokardiograficzne przezklatkowe z podaniem kontrastu zerowego - widoczne zakontrastowanie prawej komory i prawego przedsionka oraz przechodzenie kontrastu na lewą stronę serca po 3 cyklach serca

ku prowadzi do przecieku, który może wywołać hipoksemię i zator paradoksalny [2]. Wystąpienie tego zjawiska jest możliwe w okresie okołooperacyjnym jako wynik wentylacji mechanicznej, zwiększonego ciśnienia wewnątrzbrzusznego, hipotensji, zatoru lub zespołu poreperfuzyjnego, oraz przy zmienionych stosunkach anatomicznych między żyłą główną dolną i przegrodą międzyprzedsionkową [3, 4].

W literaturze dostępne są doniesienia wskazujące PFO jako przyczynę systemowych powikłań zatorowo-zakrzepowych w okresie okołooperacyjnym [4] oraz opisy skrzyżowanych zatorów powietrznych przez kanał PFO podczas operacji OLTx [5].

\section{Opis przypadku}

Pacjent, w wieku 63 lat, ze schyłkową niewydolnością wątroby marskiej w przebiegu alkoholowej choroby wątroby oraz zakażenia wirusem zapalenia wątroby typu C (HCV, hepatitis C virus) został przyjęty do Kliniki Hepatologii i Chorób Wewnętrznych Katedry Chirurgii Ogólnej, Transplantacyjnej i Wątroby Warszawskiego Uniwersytetu Medycznego celem kwalifikacji do zabiegu ortotopowego przeszczepienia wątroby. Przebieg choroby był powikłany rozwojem ogniska raka wątrobowokomórkowego. U pacjenta występowały również inne powikłania marskości wątroby, to jest nadciśnienie wrotne z obecnością żylaków przełyku (leczonych endoskopowo), splenomegalia, hipersplenizm i masywne wodobrzusze. Ponadto w wywiadach stwierdzano przewlekłą obturacyjną chorobę płuc i wieloletni nikotynizm. Podczas kwalifikacji kardiologicznej wykonano przezklatkowe badanie echokardiograficzne, w którym wysunięto podejrzenie PFO na podstawie przechodzenia dużej ilości pęcherzyków kontrastu zerowego do lewego przedsionka po 3 cyklach serca (ryc. 1). W celu potwier-

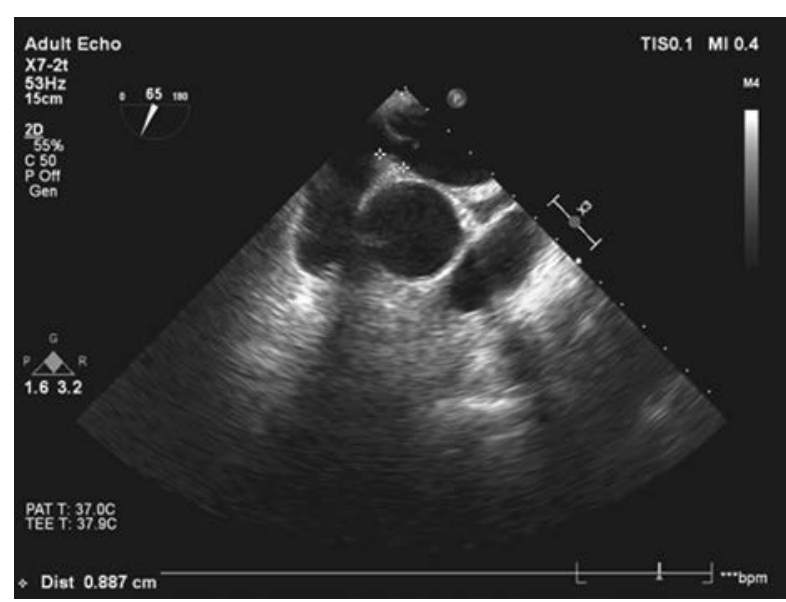

Rycina 2. Badanie echokardiograficzne przezprzełykowe - widoczny kanał przetrwałego otworu owalnego

dzenia rozpoznania wykonano echokardiograficzne badanie przezprzełykowe (TEE, transesophageal echoradiography), w którym uwidoczniono PFO - długość kanału 11-12 mm, szerokość od strony lewego przedsionka 2-3 mm, z przeciekiem lewo-prawym. W badaniu kontrastowym w trakcie próby Valsalvy zaobserwowano przechodzenie dużej ilość pęcherzyków kontrastu z prawego do lewego przedsionka. Ze względu na ryzyko embolizacji w trakcie OLTx, pacjenta zakwalifikowano do przezcewnikowego zamknięcia ubytku, podczas którego wszczepiono okluder Nit-Occlud PFO 26 mm (ryc. 2). Zabieg odbył się bez powikłań, a w kontrolnym TEE uwidoczniono prawidłową pozycję zapinki (ryc. 3, 4). Pacjentowi, z uwagi na niewydolność wątroby i zwiększone ryzyko powikłań krwotocznych, zalecono monoterapię kwasem acetylosalicylowym. Następnie u chorego wykonano zabieg transplantacji wątroby, która została przeprowadzona miesiąc po zabiegu zamknięcia PFO. Operacja również przebiegła bez powikłań.

\section{Dyskusja}

W literaturze są opisywane przypadki chorych poddawanych OLTx, u których wystąpił zator powietrzny [5]. Zaaspirowanie powietrza następuje najczęściej w momencie tworzenia zespoleń w obrębie więzadła wątrobowo-dwunastniczego i żyły głównej dolnej. Powietrze może pojawić się także po reperfuzji wszczepionego graftu, jako wynik niewystarczającego „wypłukania” łożyska naczyniowego wątroby dawcy oraz jako wynik nieszczelności w zespoleniach żylnych [5]. W przypadku występowania PFO ryzyko zabiegu operacyjnego znacząco wzrasta, gdyż predysponuje on do powstania zatoru skrzyżowanego.

Zalecenia dotyczące kwalifikacji do przeszczepienia wątroby nie określają sposobu postepowania u kandydatów z niewydolnością wątroby i PFO, co wynika z ograniczonej 


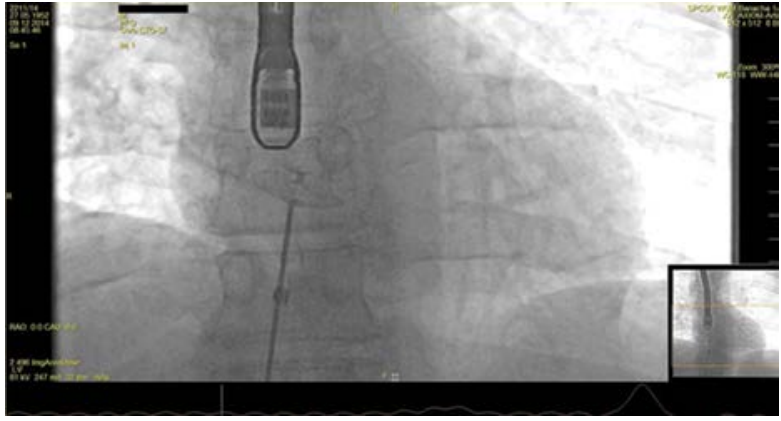

Rycina 3. Obraz fluoroskopii - widoczne pozycjonowanie zapinki podczas zabiegu przezcewnikowego zamknięcia przetrwałego otworu owalnego

liczby danych literaturowych na ten temat. Być może w kolejnych zaleceniach podejście diagnostyczne i terapeutyczne w kontekście PFO będzie sprecyzowane, ponieważ w ostatnich latach pojawiły się nowe doniesienia w tym zakresie.

Pierwszy, odmienny od poprzednich, pogląd na znaczenie PFO u pacjentów poddawanych transplantacji wątroby przedstawili Alba i wsp. W swojej pracy przeanalizowali powikłania okołooperacyjne OLTx u 27 chorych z PFO oraz grupie kontrolnej. Między grupami nie stwierdzono różnic istotnych statystycznie [6]. Ograniczeniem tego badania była jednak mała liczba włączonych pacjentów jego oraz jego retrospektywny charakter. Rozwinięciem wyżej wspomnianej pracy było opublikowane w 2016 roku badanie Werlanga i wsp. [7]. Przeprowadzili oni porównanie 97 chorych z potwierdzonym echokardiograficznie PFO, którzy zostali zakwalifikowani do OLTx, 56 chorych z przeciekiem wewnątrzpłucnym i grupą kontrolną (101 osób bez PFO). Stwierdzono podobnie długi okres pobytu pacjentów na oddziale intensywnej terapii, a w grupie PFO zaobserwowano krótszy czas zapotrzebowania na podawanie tlenu w porównaniu z grupą kontrolną. W trakcie 30-dniowej obserwacji pooperacyjnej u żadnego pacjenta z grupy PFO nie wystąpił udar. Zawraca uwagę fakt,

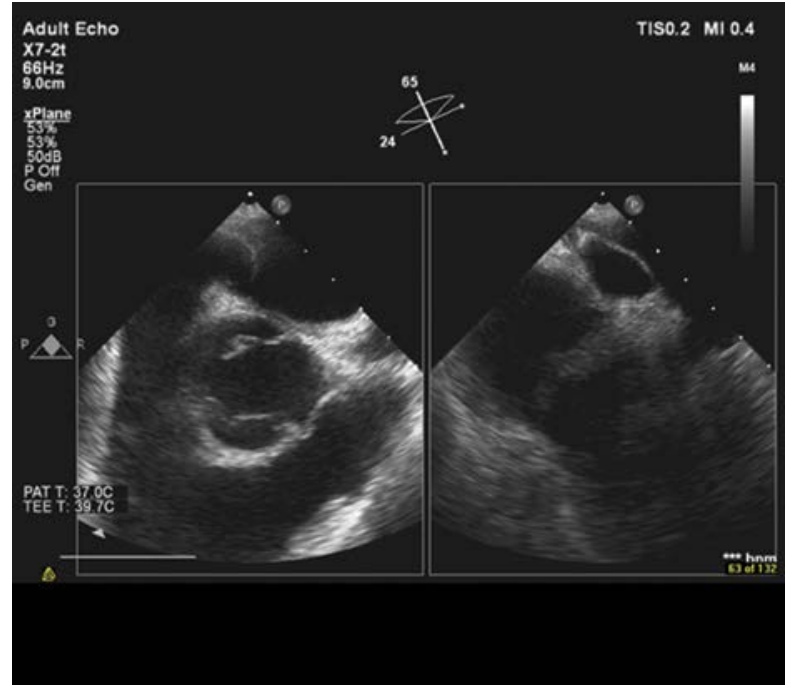

Rycina 4. Badanie echokardiograficzne przezprzełykowe - widoczna zapinka Amplatza

że w obu badaniach częstość występowania PFO u kandydatów do OLTx (odpowiednio 4\% i 10,4\%) była niższa niż w populacji ogólnej [8, 9]. Zarówno Alba i wsp., jak i Werlang i wsp. odradzają profilaktyczne zamykanie PFO u pacjentów kwalifikowanych do OLTx. Praca ta zmieniła również podejście do zamykania PFO u pacjentów kwalifikowanych do OLTx w ośrodku autorów niniejszej pracy.

\section{Podsumowanie}

W dostępnej literaturze, w momencie kwalifikacji pacjenta do zamknięcia PFO i OLTx, szczególnie w starszych opisach przypadków klinicznych wskazuje się na możliwość wystąpienia paradoksalnego zatoru powietrznego podczas OLTx. Autorzy najnowszych doniesień aktualnie odradzają profilaktyczne zamykanie PFO przed OLTX.

\section{Abstract}

Persistent foramen ovale (PFO) is a congenital defect of interatrial septum, that in majority of patients stays asymptomatic. However, in conditions that lead to increased pressure in right atrium over left atrium, it may lead to blood shunt from the right to the left atrium. We are presenting a case report of 63-years-old male who was referred to the qualification for the orthotopic liver transplantation due to the decompensated liver cirrhosis. During transesophageal echocardiography with contrast PFO was detected. In the literature cases suggesting increased perioperative risk in patients with PFO are described. It is both related to air embolisms connected with the transplantation itself and possibility of crossed embolisms. For this reason, the patient was scheduled to the transcatheter PFO closure, after which he could have liver transplantation. The operation was performed a month later, uneventfully.

Key words: end-stage liver disease, orthotopic liver transplantation, patent foramen ovale, paradoxical embolism, air embolism

Folia Cardiologica 2017; 12, 5: 493-496 


\section{Piśmiennictwo}

1. Kristensen SD, Knuuti J, Saraste A, et al. Authors/Task Force Members. 2014 ESC/ESA Guidelines on non-cardiac surgery: cardiovascular assessment and management: the Joint Task Force on noncardiac surgery: cardiovascular assessment and management of the European Society of Cardiology (ESC) and the European Society of Anaesthesiology (ESA). Eur Heart J. 2014; 35(35): 2383-2431, doi: 10.1093/eurheartj/ehu282, indexed in Pubmed: 25086026.

2. Meissner I, Whisnant J, Khandheria B, et al. Prevalence of Potential Risk Factors for Stroke Assessed by Transesophageal Echocardiography and Carotid Ultrasonography: the SPARC study. Mayo Clin Proc. 1999; 74(9): 862-869, doi: 10.4065/74.9.862.

3. De Pietri L, Mocchegiani F, Leuzzi C, et al. Transoesophageal echocardiography during liver transplantation. World J Hepatol. 2015; 7(23): 2432-2448, doi: 10.4254/wjh.v7.i23.2432, indexed in Pubmed: 26483865.

4. Sukernik MR, Mets B, Bennett-Guerrero E. Patent foramen ovale and its significance in the perioperative period. Anesth Analg. 2001; 93(5): 1137-1146, indexed in Pubmed: 11682383.
5. Olmedilla L, Garutti I, Pérez-Peña J, et al. Fatal paradoxical air embolism during liver transplantation. Br J Anaesth. 2000; 84(1): 112-114, indexed in Pubmed: 10740561.

6. Alba AC, Verocai Flaman F, Granton J, et al. Patent foramen ovale does not have a negative impact on early outcomes in patients undergoing liver transplantation. Clin Transplant. 2011; 25(1): 151-155, doi: 10.1111/j.1399-0012.2010.01210.x, indexed in Pubmed: 20156223.

7. Werlang ME, Palmer WC, Boyd EA, et al. Patent foramen ovale in liver transplant recipients does not negatively impact short-term outcomes. Clin Transplant. 2016; 30(1): 26-32, doi: 10.1111/ctr.12643, indexed in Pubmed: 26448343.

8. Hagen PT, Scholz DG, Edwards WD. Incidence and size of patent foramen ovale during the first 10 decades of life: an autopsy study of 965 normal hearts. Mayo Clin Proc. 1984; 59(1): 17-20, indexed in Pubmed: 6694427.

9. Meissner I, Khandheria BK, Heit JA, et al. Patent foramen ovale: Innocent or guilty? J Am Coll Cardiol. 2006; 47: 440-445, doi: 10.1016/j. jacc.2005.10.044, indexed in Pubmed: 16412874. 